\title{
Carta da Editora
}

Estimados leitores e leitoras,

É com imensa satisfaçáo que disponibilizamos aos leitores o número 66, referente a set./dez. de 2018 da Revista de Educação Pública, encerrando os números editados nesse ano. As discussóes apresentadas em seus diferentes artigos reúnem reflexóes conduzidas por pesquisadores brasileiros e portugueses, reiterando a pluralidade institucional e o vasto campo das pesquisas em Educaçáo. A alusão aos títulos nos permite entrever a potencialidade dos estudos que integram a revista, evidenciando uma interlocução que busca o reinventar a cada instante, pois quando se trata de ciência humana só sabemos junto com os outros (FERRAROTTI, 2014). ${ }^{1}$

O primeiro artigo, Políticas de Educação Infantil: conquistas, embates e desafios na construção de uma Pedagogia da Infância, destaca que os modos de educar as crianças têm constituído uma arena de disputas produzida em um sistema de relaçóes de poder, no qual direitos sociais conquistados precisam ser reafirmados para que não sejam perdidos.

Na sequência, o trabalho intitulado Contribuiçóes da estética à ação pedagógica na EJA: ressonâncias formativas na escola e na universidade focaliza a estética e suas relaçóes com o campo da ética, articulando os saberes da universidade e da escola e refletindo sobre os desafios atuais enfrentados na EJA.

Com $A$ presença do jogo na infância de octogenários e nonagenários busca-se conhecer diferentes manifestaçôes da cultura lúdica na infância de octogenários e nonagenários, vivida nas décadas de 20 e 30, considerando que as distintas configuraçôes assumidas pela infância produzem diferentes cenários que podem influenciar a forma e o conteúdo da constituição da cultura lúdica.

A contribuição do estudo Representaçóes sociais de futuros docentes sobre a Teoria da Evolução darwinista aponta forte ligação entre a Teoria da Evolução e a imagem de Darwin. Mesmo com o passar de 150 anos, teoria e autor estão presentes no conhecimento popular, rompendo as barreiras do universo científico para circular amplamente nas representações desses futuros professores.

Homens podem ser feministas? O pioneirismo dos estudos de masculinidades no Nordeste do Brasil aborda o surgimento dos estudos de masculinidades e a possibilidade de uma identidade feminista de sujeitos homens.

1 FERRAROTTI, Franco. História e histórias de vida. Tradução: Carlos Eduardo Galvão, Maria da Conceição Passeggi. Natal: EDUFRN, 2014. 
Em Educação, poder e ordem: política e quotidiano numa escola de formação de professores, centrado na Escola do Magistério Primário de Coimbra (EMPC), entre 1942 e 1974, interpreta-se o modelo pedagógico, polarizando nos conceitos de educação, poder e ordem, tendo como pano de fundo a relação dialética entre a norma e as práticas sociais.

Compóe também o artigo Práticas educativas nas instituiçóes de acolhimento sob o olhar das crianças, indicando que o lugar é percebido como disciplinar, de imposição de regras, de privação e ambivalências nas práticas educativas.

Pedagogias da alteridade. Perspectivas sobre a emoção de lidar: Manuela Malpique e Nise da Silveira apresenta a obra de duas personalidades singulares nas suas áreas de atuação, cujos interesses um dia se cruzaram, evidenciando a relação entre educação, terapia e arte teorizada e praticada pelas biografadas.

A seguir, A escolarização da infância rural no espaço luso-brasileiro na perspectiva da educação comparada (1935 a 1945) analisa produçôes acadêmicas e legislaçóes dos países, privilegiando categorias que permitiram aproximar/distanciar das realidades o acesso, as modalidades escolares e o currículo.

No artigo Avaliação no Ensino Médio Politécnico como processo de construção de saber na relação professor-aluno, enfatizam-se as contribuiçóes dessa metodologia avaliativa na formação do sujeito crítico, reflexivo e autônomo.

Como último artigo, Interdisciplinaridade: desafios e potencialidades de uma proposta articulada ao estágio docente do Curso de Física/PARFOR sinaliza potencialidades de açóes interdisciplinares, desafios para sua realização na Educação Básica e possibilidades para superá-los.

Por fim, esperamos que o número ora publicado desencadeie indagaçóes e diálogos produtivos, instigando outras significativas reflexóes, investigaçóes e práticas. Assim, expressamos nossos desejos de ver os artigos e resenhas aqui apresentados sendo cada vez mais consultados e citados em trabalhos de conclusáo de cursos, dissertaçóes de mestrado e teses de doutorado. E agradecemos aos autores, pareceristas e equipe técnica pela inestimável contribuição e compromisso, o que torna possível a concretizaçáo de cada número desta Revista.

Filomena Maria de Arruda Monteiro Editora da Revista de Educação Pública IE/UFMT 